\title{
DIAGNOSTIC POTENTIAL OF MIRNAS IN PARATHYROID CARCINOMAS
}

A. Ladang, Y. Seynaeve, E Cavalier

Department of Clinical Chemistry, ULiège and CHU of Liège, Belgium

\section{Introduction:}

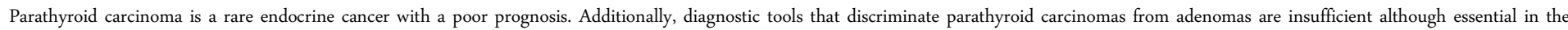

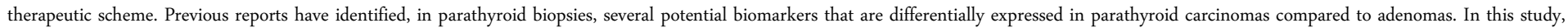
we investigate the expression profile of those previously reported miRNAs in sera of patients suffering from parathyroid carcinoma.

\section{Material and Methods:}

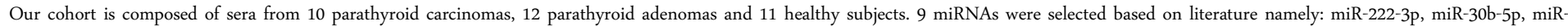

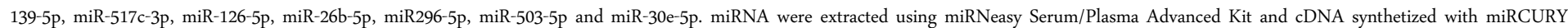
LNA RT Kit. miRNA expression profile was quantified by real-time qPCR assays Lightcycler (Roche ${ }^{\circ}$ ) using miRCURY LNA SYBR Green PCR Kit.

\begin{tabular}{|c|c|c|c|c|}
\hline & Parathyroid carcinomas & Parathyroid adenomas & Healthy subjects & \\
\hline $\mathrm{n}$ & $3+-7 \delta^{\star}$ & 5 우 $70^{1}$ & 5 우 $60^{\lambda}$ & \\
\hline Age (years) & $49,3 \pm 13,5$ & $61,4 \pm 11,3$ & $58 \pm 19,7$ & \\
\hline Calcium (mmol/L) & $3,58 \pm 0,5$ & $2,91 \pm 0,4$ & $2,4 \pm 0,1$ & Fig 1. Demographic \\
\hline Phosphates ( $\mathrm{mmol} / \mathrm{L})$ & $0,654 \pm 0,2$ & $0,76 \pm 0,2$ & $0,99 \pm 0,2$ & characteristics of the \\
\hline PTH (ng/L) & $1211 \pm 1563,9$ & $86,7 \pm 75,6$ & $17,8 \pm 5,7$ & studied population. \\
\hline 25-OH-VTD (ng/mL) & $12,2 \pm 6,7$ & $32,6 \pm 7,3$ & $29,2 \pm 7,2$ & \\
\hline Creatinine $(\mathrm{mg} / \mathrm{mL})$ & $14,6 \pm 3,7$ & $10,96 \pm 3,7$ & $10,8 \pm 3,1$ & \\
\hline GFR & $44,6 \pm 15,6$ & $56,7 \pm 6,9$ & $54,4 \pm 7,2$ & \\
\hline
\end{tabular}

Results:
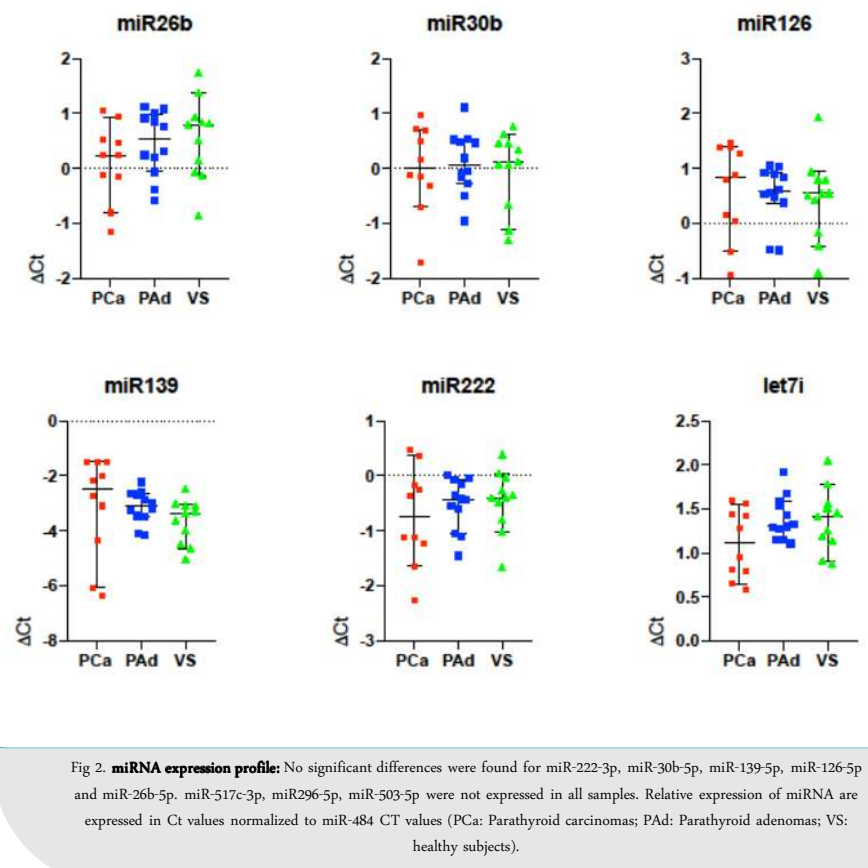
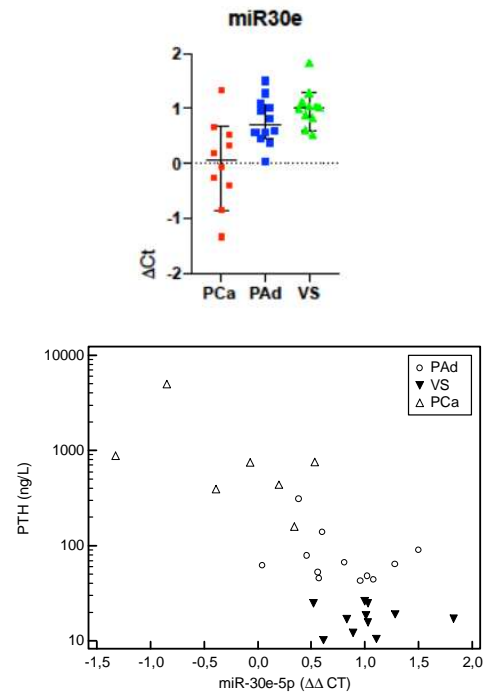

Fig 3. miR-30e-5p expression: (Upper graph): miR-30e-5p was significantly differentially expressed in parathyroid carcinomas compared to the other subpopulations. (Lower graph): A significant logarithmic correlation was observed between miR-30e-5P and PTH values. Relative expression of miRNA are expressed in $\mathrm{Ct}$ values normalized to miR-484 CT values (PCa: Parathyroid carcinomas; PAd: Parathyroid adenomas; VS: healthy subjects).

\section{Conclusions:}

This study identifies miR-30e-5p as potential serum biomarker for parathyroid carcinomas. It also shows that previously reported miRNA identified in parathyroid carcinoma biopsies are not inapplicable in serum matrix. Given the frequency of the disease, we believe that those results are interesting but should be confirmed by other studies. 